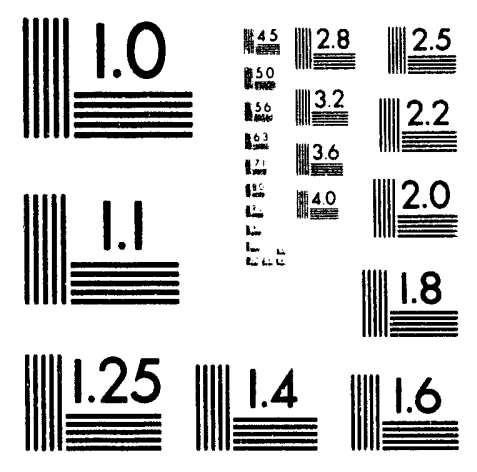



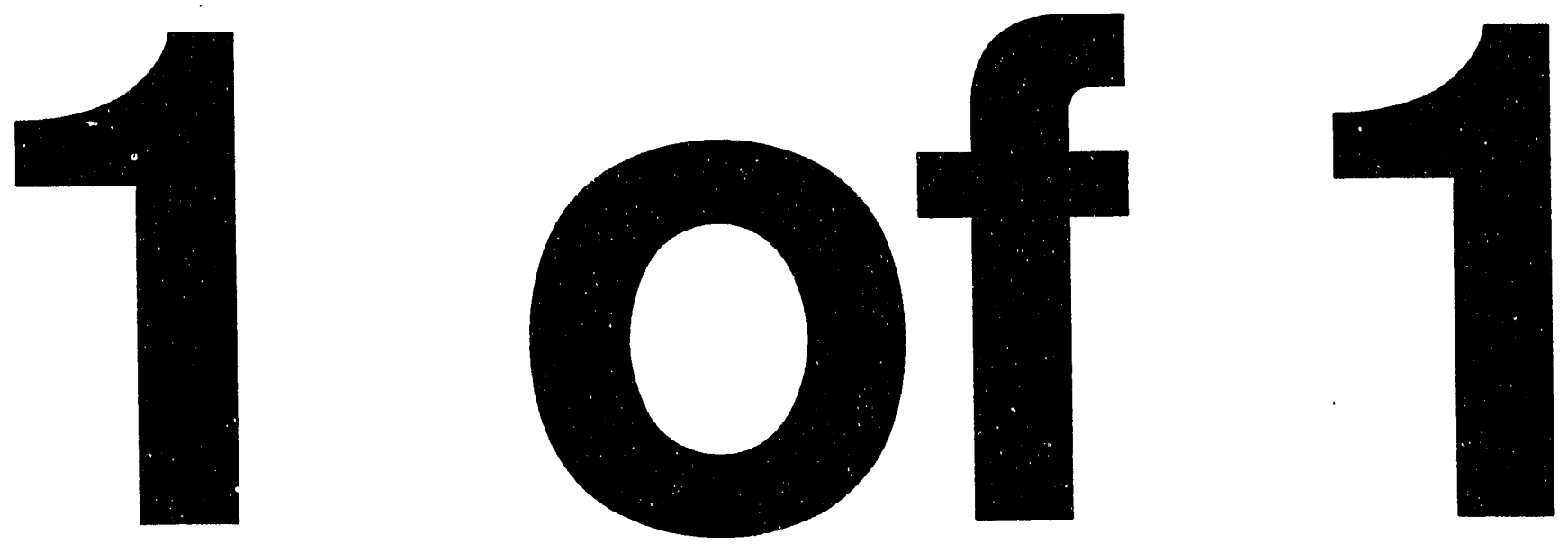


\section{NATIONAL PROGRAM PLAN}

\section{FUEL CELLS IN TRANSPORTATION}

\section{EXECUTIVE SUMMARY}
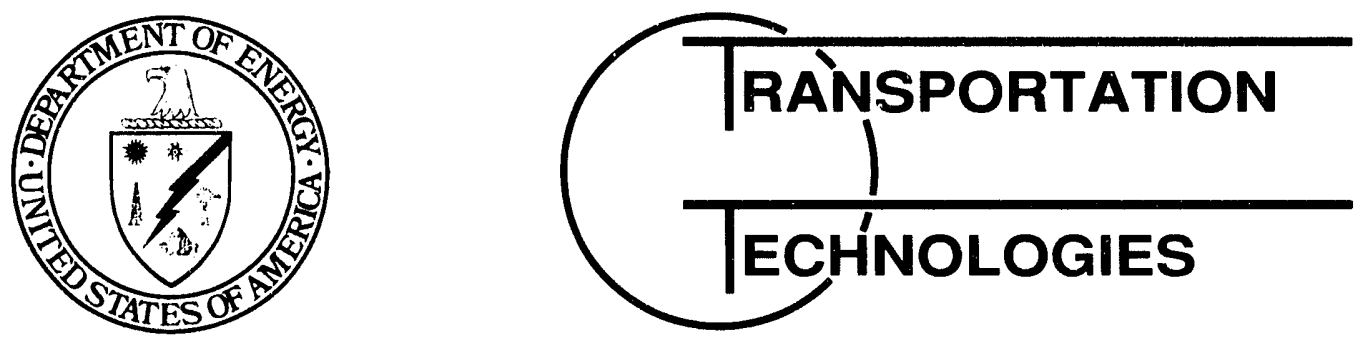

OFFICE OF PROPULSION SYSTEMS

CONSERVATION AND RENEWABLE ENERGY

February 1993 


\section{Table of Contents}

National Program Plan

Fuel Cells in Transportation

INTRODUCTION A. Page




\section{National Program Plan Fuel Cells in Transportation

Exhibit 1. Transportation Accounts for over 27\% of U.S. Primary

Energy Consumption

Exhibit 2. Over 63\% of Petroleum Usage Is Due to the

Transportation Sector

Exhibit 3. Despite New Vehicle Emissions Reductions,

Transportation Is a Significant Polluter

Exhibit 4. Successful Deployment of Fuel Cells in Transportation Can Have Dramatic Energy and

Environmental Impact on the Nation

Exhibit 5. Fuel Cell Technology Reduces Airborne Emissions of

Pollutants from Vehicles to Negligible Levels, Even

Compared to Rigorous California ULEV Standards

Exhibit 6. Fuel Cell Vehicles Utilize Electric-Vehicle Drivetrains

and Produce Power by Electrochemical Means

Exhibit 7. The Fuel Cells in Transportation Program Relies

on Linkages to Related Programs

Exhibit 8. The Program Plan Elements Provide Multiple

Opportunities for Success

Exhibit 9. The Research, Development, and Demonstration

Schedule for Fuel Cell Power Systems Will

Hasten Commercialization of FCVs

Exhibit 10. The Principal Stakeholders Have Diverse

Concerns and Potential Contributions

Exhibit 11. The National Fuel Cells in Transportation Program

Relies on Industry/Government Alliances to

Implement the Program

Exhibit 12. Project Alliances Assure Stakeholder Input into the Fuel Cells in Transportation Development Program 


\section{INTRODUCTION $\begin{aligned} & \text { National Program Plan } \\ & \text { fuel Cells in Transportation }\end{aligned}$}

The National Program Plan for Fuel Cells in Transportation describes a U.S. Department of Energy (DOE) R\&D program with the goal of developing an alternative to internal combustion engines (ICEs) for the U.S. transportation sector.

Major contributions to the Plan have resulted from two meetings of an ad hoc technical panel, which brought together more than 50 representatives from the transportation industry, universities, national laboratories, government agencies, regulatory bodies, and alternative fuels proponents, all with heightened interest in the development of fuel cell vehicles (FCVs). The Plan reflects the collective expertise of the group in three main areas: vehicle systems, fuel cell technology, and policy and institutional factors and infrastructure-related issues. The initial formation of a consensus for the development and commercialization of FCVs was an important outcome of these two meetings.

This Plan addresses the FCV-related requirements in Sections 2025(j) and 2026 of the Energy Policy Act of 1992, Public Law 102-486 (EPACT).

\section{THE COMPREHENSIVE NATIONAL ENERGY POLICY ACT MANDATES THE DEVELOPMENT OF FUEL CELL VEHICIES.}

The Energy Act directs the Secretary of Energy "... to develop and implement a comprehensive program of research, development, and demonstration of fuel cells and related systems for transportation applications through the establishment of one or more cooperative programs among industry, government, and research institutions to develop and demonstrate the use of fuel cells as the primary power source for private and mass transit vehicles and other mobile applications." The development activities are to apply to the following: "... passenger vehicles; vans and utility vehicles; light rail systems and locomotives; trucks, including long-haul trucks, dump trucks, and garbage trucks; passenger buses; non-chlorofluorocarbon mobile refrigeration systems; marine vessels, including recreational marine engines; or mobile engines and power generation, including recreational generators, and industrial and construction equipment." Development of fuel cells for marine applications, mobile refrigerators, and mobile engines is being sponsored by the Department of Defense (DOD) and the National Aeronautics and Space Administration (NASA). Therefore, DOE will concentrate on fuel cell systems for vehicle propulsion and will coordinate its development activities with DOD and NASA to ensure that the provisions of the Act are carried out.

In addition to the Energy Act, the National Energy Strategy recognizes that any policy to reduce petroleum consuription in the transportation sector will require dramatic increases in transportation energy efficiency and the use of alternative fuels. Moreover, the President's National Critical Technologies Panel has identified fuel cells as one of the 22 technologies considered essential for the United States to develop and utilize in order to achieve economic prosperity and maintain national security. 
National Program Plan Fuel Cells in Transportation 


\section{A NATIONAL STRATEGY TO REUUCE PETROLEUM DEPENDENCY AND IMPROVE AIR QUALITY MUST FOCUS ON THE TRANSPORTATION SECTOR.}

- The transportation sector is the major contributor to petroleum dependency. In the United States, the transportation sector consumes more petroleum than any other energy-use sector. Transportation presently accounts for one-fourth of all U.S. energy consumption and two-thirds of the petroleum usage (Exhibits 1 and 2). In 1991, petroleum use for transportation exceeded U.S. production by $36 \%$ and, combined with diminishing U.S. production, was largely responsible for increasing oil imports $(\$ 44$ billion, which represented two thirds of the trade deficit in 1991). Even though fuel consumption per vehicle-mile has been reduced by about $40 \%$ from 1970 levels, the number of miles traveled has increased from 1 trillion in 1970 to 2 trillion in 1990.
- The transportation sector is the major contributor to air-quality problems in urban areas. Emissions per vehicle-mile have been reduced by about $80 \%$ from 1970 levels. However, because of the dramatic increase in vehicle miles traveled, motor vehicles today still remain responsible for about one-half of the pollutants that form smog in our cities, over $60 \%$ of the carbon monoxide, and about one-third of the lead and volatile organic compounds (VOCs) (see Exhibit 3). Moreover, without technological breakthroughs, adverse energy and environmental impacts are forecast to increase at a rate that will offset gains in new vehicle efficiency and emissions control because of projected increases in the vehicle fleet size and in the miles traveled.

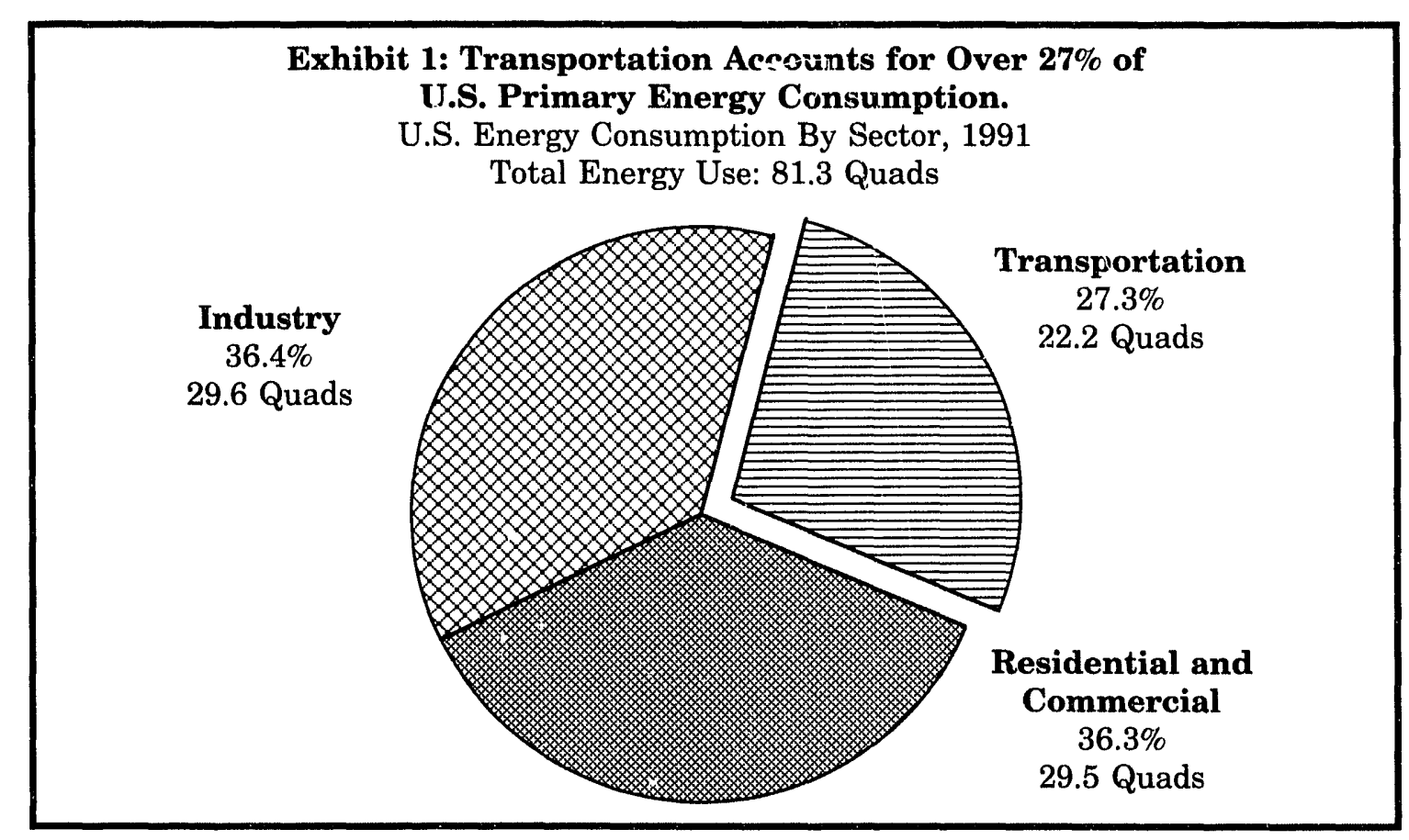


National Program Plan

Fuel Cells in Transportation

Exhibit 2: Over 63\% of Petroleum Usage is Due to the Transportation Sector. U.S. Petroleum Use By Sector, 1991

Total Petroleum Use: 32.8 Quads

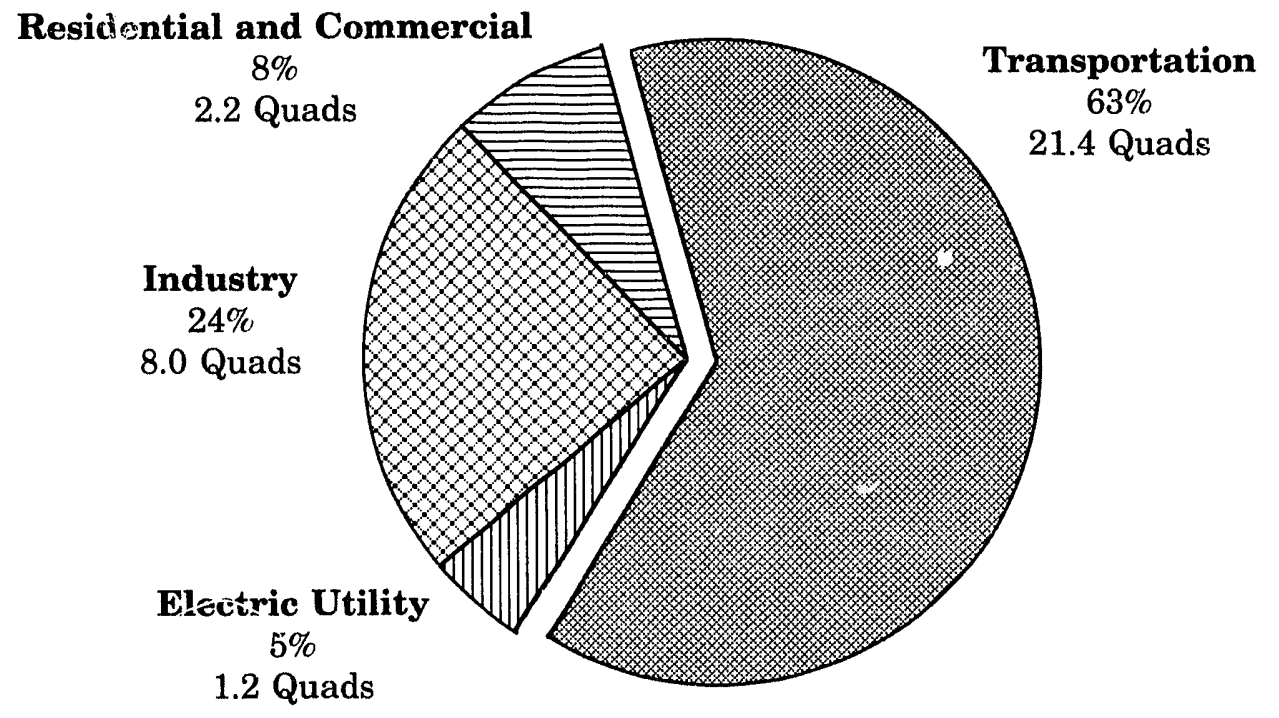

Exhibit 3: Despite New Vehicle Emissions Reductions, Transportation is a Significant Polluter.

Transportation Share of Emissions

Still a major contributor, despite reductions in new vehicle emissions achieved over the past decade.
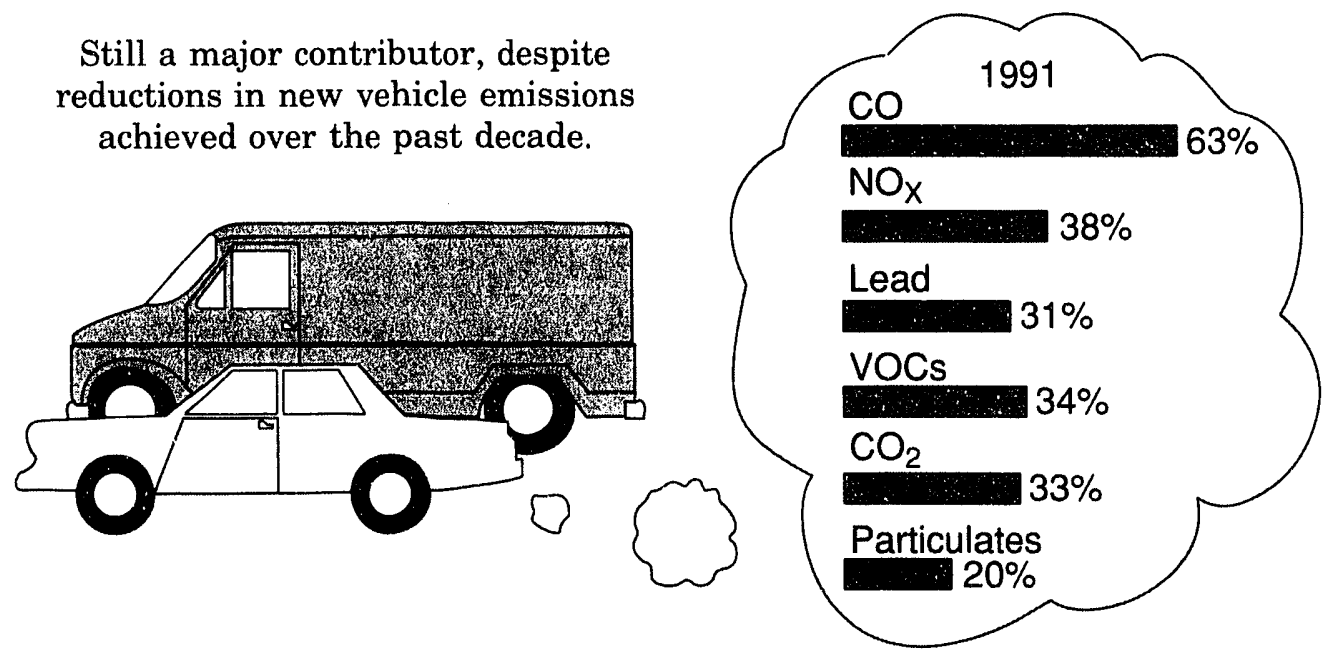


\section{Program Benefits $\begin{aligned} & \text { National Program Plan } \\ & \text { Fuel Cells in Transportation }\end{aligned}$}

The objectives of the Plan are focused on achieving the following national benefits: reducing the U.S. dependence upon petroleum fuels, minimizing air pollution from the transportation sector, and affirming the
U.S. leadership in fuel cell development, manufacturing, and commercialization. The impact of a successful program on emissions and petroleum usage in the United States is illustrated in Exhibit 4.

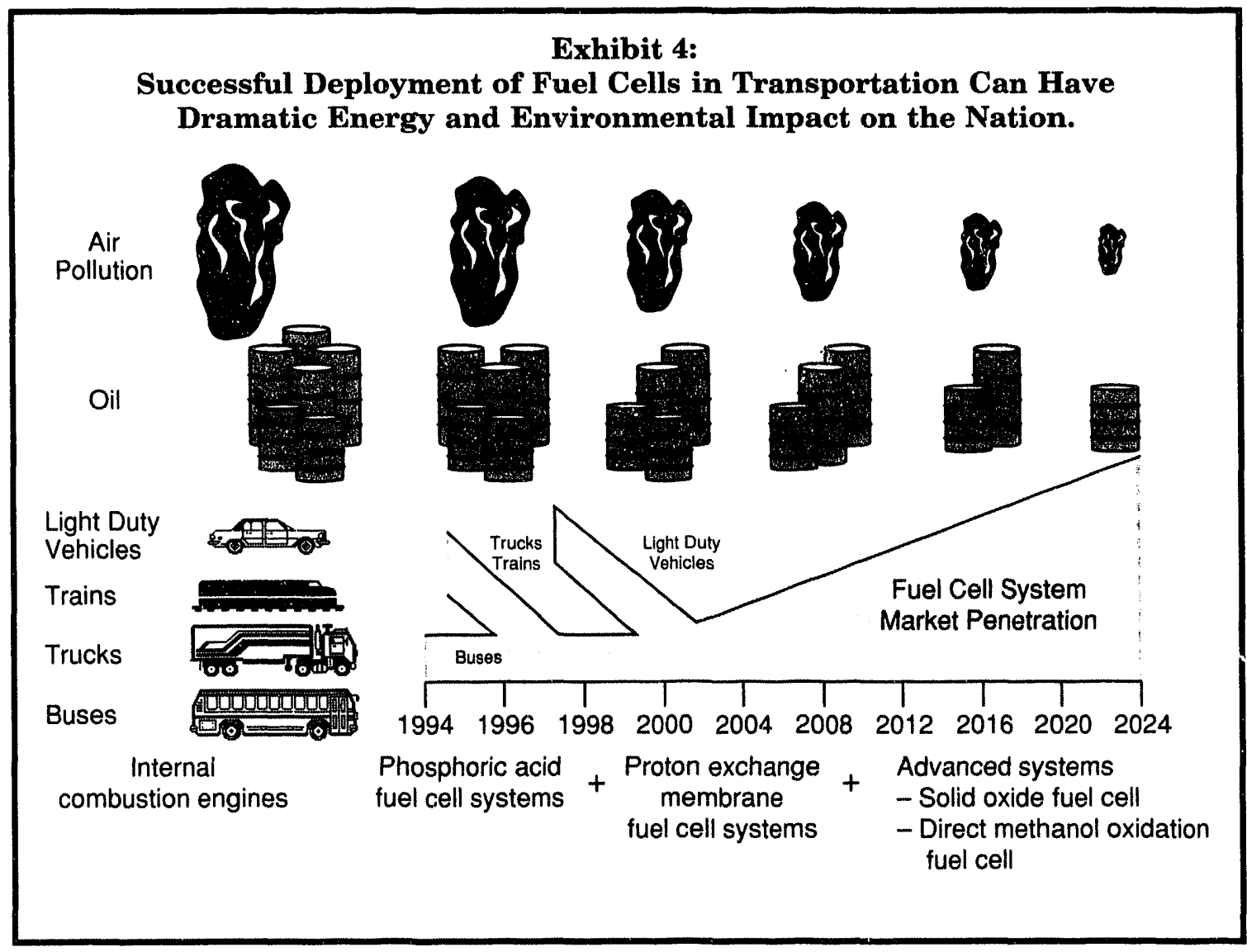

\section{FUEL CELL VEHICLES WILL RESULT IN SUBSTANTIAL REDUCTIONS IN PRIMARY ENERGY USE, PARTICULARLY OIL IMPORTS.}

Fuel cell vehicles, if successfully commercialized, can reduce the nation's reliance on petroleum and provide impetus for a switch to indigenous fuel forms, primarily natural gas (or methanol derived from natural gas) and ethanol. The efficiency with which hydrogen is converted into electricity ranges between $50 \%$ and $65 \%$, depending on fuel cell technology and operating conditions. Fuel cell-powered vehicles are projected to attain efficiencies of $35-55 \%$ after thermal and parasitic power losses are taken into account. Efficiencies for current ICE vehicles are only about $18 \%$. Thus, FCVs can achieve a per 


\section{National Program Plan Fuel Cells in Transportation}

vehicle reduction in energy consumption of at least $50 \%$. Significant reductions in petroleum use could occur after the year 2000, as the result of commercialization phases for heavy-duty vehicles projected to start before the end of this decade. Even with only a $10 \%$ market penetration (based on miles traveled), reduced oil imports could reach over 800,000 barrels a day, assuming on-board methanol reformation.
The near-term market for FCVs will be driven by environmental considerations, namely, Zero Emission Vehicle (ZEV) requirements. The long-term market prospects for FCVs, however, will be determined by economics - is the FCV competitive with then-current vehicle alternatives which also meet environmental, safety, and other requirements?

\section{FUEL CELL VEHICLES WILL PLAY AN IMPORTANT ROLE IN ACHIEVING REGULATORY REQUIREMENTS FOR AMBIENT AIR QUALITY IN URBAN AREAS.}

In areas with severe air-quality problems, such as southern California, it is now recognized that dramatic emissions reductions from even the best current practice will be required to meet regulatory requirements. This is reflected in the highly publicized requirements to introduce $\mathrm{ZEVs}$ into the southern California fleet before the end of the decade. Adopting these requirements is also being considered by more than 13 other states, representing over $30 \%$ of the national vehicle market.

An FCV operated on methanol can achieve emission levels for $\mathrm{CO}$, NOx, and nonmethane organic gas (NMOG) substantially less than those levels established for the California Ultra Low Emission Vehicle (ULEV) standards. Exhibit 5 iilustrates projected emissions of FCVs relative to current and future standards. If hydrogen is used for fuel, the FCV will be a ZEV.
The focus of near-term markets for fuel cell vehicles will be urban areas having severe air-quality problems. The nearly negligible emissions from fuel cells in both light-duty and heavy-duty vehicles (buses, trucks, urban train systems, trolleys) will make a major contribution toward reducing transportation sector emissions to regulatory defined limits. Because fuel cell vehicles are expected to provide the same performance and range as a gasoline vehicle, a market penetration that exceeds the current ZEV regulatory mandates (e.g., $2 \%$ by 1998 ) can be expected in California and other states with similar requirements, albeit with some time lag. This increased market penetration will lead to imp:oved overall energy efficiency and air quality in urban areas. For example, a $10 \%$ market penetration of fuel cell vehicles will reduce emissions of regulated air pollutants by over 1 million tons a year and will also reduce emissions of carbon dioxide by over $60 \mathrm{mil}$ lion tons a year. 


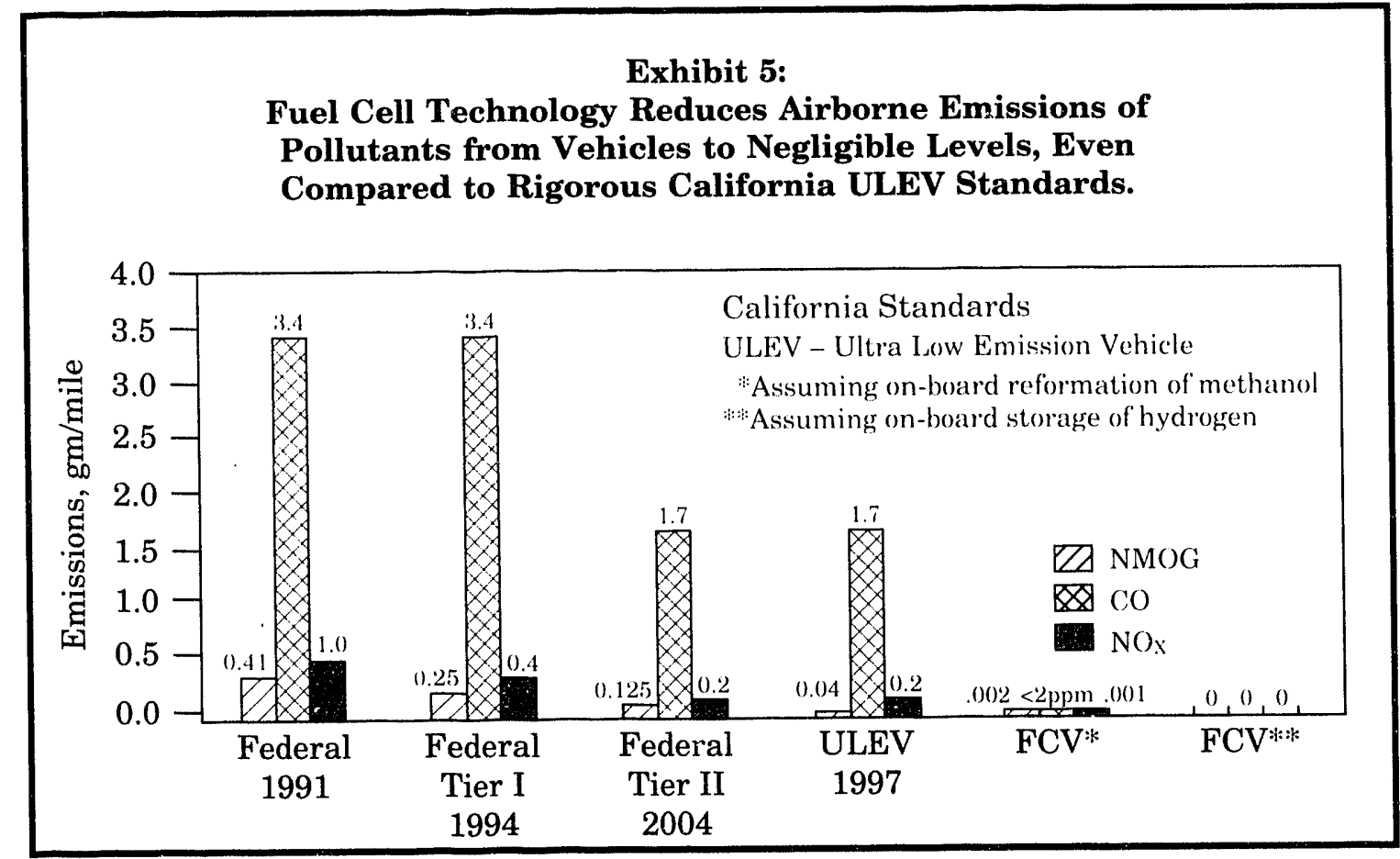

\section{A SUCCESSFUL TRANSPORTATION FUEL CELL PROGRAM WILL GREATLY ENHANCE THE INTERNATIONAL COMPETITIVENESS OF U.S. INDUSTRY IN THE WORLDWIDE TRANSPORTATION SECTOR.}

The transportation sector accounts for $\$ 975$ billion in gross domestic product and over 13 million jobs in the United States. Its health is absolutely essential to the economic well being of the country. The energy/ environmental issues which are driving the U.S. fuel cell program are also of intense interest in all the industrialized countries. As a consequence, a worldwide market for fuel cell vehicles is anticipated once the technology is established. This is indicated by the growing commitments in Japan and Europe to develop fuel cell technology for vehicle propulsion applications.
U.S. corporations with established engineering, development, and manufacturing facilities related to fuel cells are seeking to attain a position at the forefront of transportation fuel cells, while simultaneously maintaining leadership in multi-kilowatt and multimegawatt stationary plants. Accordingly, activities in the DOE Fuel Cells in Transportation Program will be focused on establishing U.S. leadership in the development of fuel cells for transportation, which, in turn, will lead to increased export opportunities and the creation of jobs. 


\section{National Program Plan Fuel Cells in Transportation}

\section{MANUFACTURING OF TRANSPORTATION FUEL CELLS ON A LARGE SCALE WILL HELP EXPAND THE MARKET FOR STATIONARY APPLICATIONS, THEREBY PROVIDING ADDITIONAL ECONOMIC BENEFITS.}

The fuel cell manufacturing demands associated with transportation applications are potentially far larger than for stationary applications. For example, even a modest 100,000 light-duty vehicles per year would result in over 4,000 MW of production - a production level not easily achieved in stationary applications. These production levels are essential for driving down cost and will provide important support for rapidly expanding the market for stationary systems in such vital applications as building heating/cooling and power cogeneration. 


\section{TECHNOLOGY DESCRIPTION AND Status}

\section{FUEL CELLS USE AN ELECTROCHEMICAL PROCESS TO CONVERT HYDROGEN AND OXYGEN INTO ELECTRICITY.}

A fuel cell is an elec rochemical device that converts the energy of a chemical reaction directly into electrical energy. Unlike heat engines such as ICEs, there is no combustion process which generates airborne pollutants. In a typical fuel cell system, hydrogen and oxygen (from air) react electrochemically to produce electricity, heat, and water. No recharging of the fuel cell is necessary; as long as hydrogen fuel and air are supplied to the fuel cell, it continues to produce power. The hydrogen may be stored as a pure gas; or a hydrogen-containing fuel, such as methane, methanol, or ethanol, may be processed (reformed) to detach the hydrogen for consumption in the fuel cells.

A simplified schematic of a fuel cell power system for transportation applications is shown in Exhibit 6. When the anode and the cathode are electrically connected through an external load, the following events occur:
- the catalyzed anode reacts with hydrogen to form hydrogen ions and electrons;

- the hydrogen ions are conducted through the electrolyte to the surface of the catalyzed cathode;

- the electrolyte acts as a gas barrier to electron flow; therefore, the electrons are compelled to flow through an external load, generating electric current; and

- the hydrogen ions, electrons, and bubbled oxygen react on the cathode's surface to form water.

The net reaction of this simplified fuel cell produces water and electrical current from hydrogen and oxygen. Practical fuel cell designs allow for many individual fuel cells to be connected in series with an appropriate interconnect material to form a stack.

\section{SEVERAL FUEL CELL TECHNOLOGIES CAN BE USED IN TRANSPORTATION APPLICATIONS.}

Four fuel cell technologies are being considered for use in transportation applications:

- Phosphoric Acid Fuel Cell (PAFC)

- Proton Exchange Membrane Fuel Cell (PEMFC)

- Solid Oxide ruel Cell (SOFC)

- Direct Methanol-Air Fuel Cell (DMAFC)

These technologies have unique combinations of attributes, which make them attractive for different applications.

The PAFC technology, which is well suited for heavy-duty transportation applications, is the focus of the current DOE-sponsored Urban Transit Bus Program. The PAFC is the most advanced of the options. More than ten stationary PAFC power plants fabricated by International Fuel Cells/ONSI are already installed and operating, and approximately 50 more will be placed in service during 1993. Their $200 \mathrm{~kW}$ rating is consistent with the range required for bus and truck applications. A 500-1000 kW fuel cell system has been developed and is being used in stationary power plants (1-11 MW), providing a starting point for development of locomotive units.

The ongoing DOE-supported Light-Duty Vehicle Program is based on the use of PEMFC technology, because of its high power density and compatibility with rapid load- 


\section{National Program Plan Fuel Cells in Transportation}

cycling operation. The PEMFC technology is also being develcped for various space and undersea applications in capacities ranging up to $25 \mathrm{~kW}$.

The SOFC technology has been demonstrated at the $25 \mathrm{~kW}$ size for stationary applications and is being evaluated for several different applications due to its potential for simplified on-board fuel processing, high power density, and low costs. The DMAFC is the least developed of the fuel cell technologies and is being considered for the transportation application for the same reasons as the SOFC, namely, the potential for better performance at lower costs.

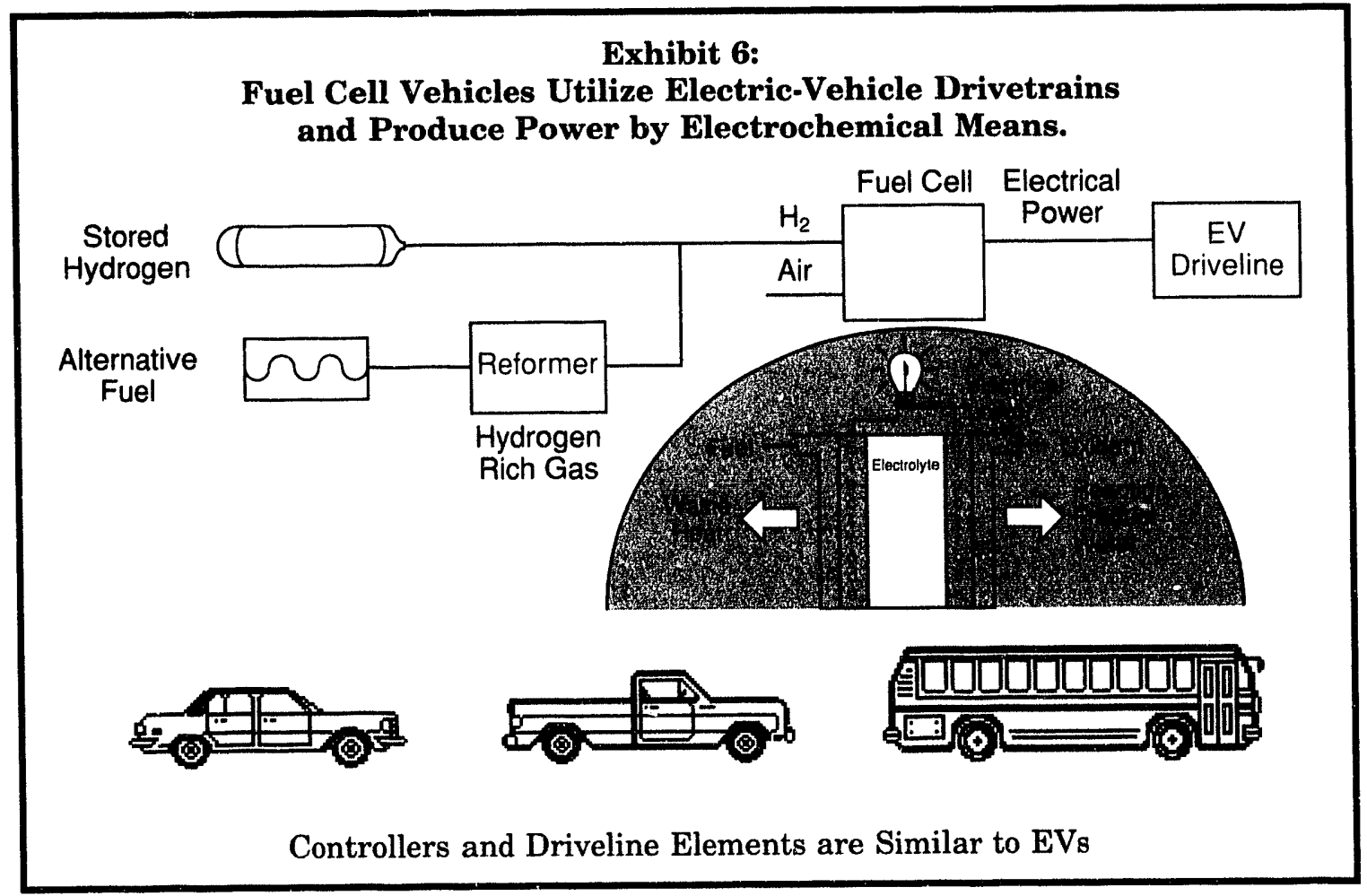




\section{National Program Plan Fuel Cells in Transportation}

\section{FUEL CELL DEVELOPMENT MUST CLEAR SEVERAL HLRDLES BEFORE SUCCESSFUL TRANSPORTATION APPLICATIONS ARE POSSIBLE.}

The operating conditions of, and design constraints on, fuel cells when used in transportation applications differ considerably from stationary applications. These differences constitute the major hurdles to success for the fuel cells in transportation program.

- The size/weight of current designs precludes their use in many applications particularly light-duty vehicles, which account for over $50 \%$ of transportation fuel use. The power density of fuel cells ( power output per unit volume or weight) needs to be improved - fuel cell output must be increased or the size and weight of the fuel cell and/or auxiliary equipment must be decreased.
- Conventional designs for fuel cell systems do not have the rapid start-up time and load-following capability required for most transportation applications. Lightduty vehicles have greatest need for rapid start-up and load-following capability.

- Stationary system designs are too costly for widespread use in transportation applications. Decreased materials costs and improved designs are required.

- Fuel cell vehicles will utilize some combination of fuels imethanol, hydrogen, natural gas, ethanol) for which an infrastructure is not yet available; this could become a barrier to large-scale use. 
National Program Plan

Fuel Cells in Transportation 


\section{Program Strategy}

\section{THE TECHNICAL STRATEGY FOCUSES ON ISSUES UNIQUE TO TRANSPORTATION APPLICATIONS.}

The program focuses on the technical, cost, and infrastructure hurdles which must be overcome if fuel cell technology is to become widely utilized in the transportation sector.

Size and weight are being addressed both in basic fuel cell technology and in propulsion system development. For instance, the program is developing the following:

- Integrated system designs that are compactly packaged.

- Compact on-board fuel reformers.

- On-board hydrogen storage systems.

- Improved fuel cell designs using lighter weight materials without compromising the mechanical integrity of the fuel cell.

Rapid start-up and load-following capability are the subject of the following developments:

- Reformers with inherent load-following capability.

- Improved PEMFC technology with quick start-up capabilities from a cold condition.

- Designs which incorporate batteries, ultracapacitors, or hydrogen storage to improve dynamic response and handle load surges.
Cost hurdles are being overcome by:

- Taking advantage of the lower lifetime requirements for mobile fuel cell power systems, compared to stationary systems, to develop fuel processing and stack designs specific to the transportation sector. These include reduced catalyst loadings, lighter weight construction, and selection of appropriate components (blowers, etc.).

- Developing designs which either simplify the overall system (for example, use of on-board hydrogen storage) or reduce fuelcell capacity requirements.

- Developing fuel-cell stack technology with higher power density - based on improvements in PEMFC, SOFC, and DMAFC.

Fuel infrastructure issues are being addressed by:

- Developing multifuel reforming capability which provides some level of fuel use flexibility.

- Defining fuel infrastructure issues (supply and distribution) and approaches for their resolution.

- Coordinating activities with alternative fuels developers in government and industry. 


\section{National Program Plan Fuel Cells in Transportation}

\section{THE PROGRAM PURSUES MULTIPLE TECHNOLOGY PATHS TO REDUCE DEVELOPMENT RISKS AND TO ADDRESS DIFFERENT MARKET SECTORS.}

The progran involves concurrently emphasizing relatively near-term, low-risk technologies and applications (e.g., phosphoric acid fuel cells in buses) and longer-term, higher-risk technologies and applications (e.g., proton exchange membrane and solid oxide fuel cells in automobiles and other vehicles).

Heavy-duty vehicular applications are an important part of the program because of the relative ease with which existing fuel cells could be integrated into the vehicle chassis. The PAFC bus program will provide early experience with FCVs in a market segment with potentially significant energy and environmental benefits. The development program for the PEMFC light-duty vehicle was undertaken because the PEMFC offers the rapid start-up and performance attributes required in this market segment with the greatest potential energy and environmental benefits. Other light- and heavy-duty applications are being selected and ranked in order of potential benefits and the availability of research and development funds. Each program element contains appropriate go/no-go decision points that provide the opportunity to assess progress and redirect specific activities.

Ongoing analysis defines R\&D needs and establishes the feasibility and the benefits of the introduction of fuel cell technology into each transportation system and market sector. The results of the analyses are used to establish program priorities. Fuel cellpowered locomotives will receive initial attention.

Fundamental research is being pursued to advance the technology from a cost, performance, and reliability standpoint. Technological improvements are then transferred to the propulsion system development programs. 


\section{THE PROGRAM RELIES ON LINKAGES WITH EXISTING PROGRAMIS.}

The compelling energy efficiency and environmental benefits of fuel cell technology for stationary applications have been recognized for over 20 years. To date, over $\$ 1$ billion in resources have been expended by organizations such as the Department of Energy (DOE, Office of Fossil Energy), the Gas Research Institute (GRI), Electric Power Research Institute (EPRI), NASA, DOD, and industry in developing the basic technology. At present, significant ongoing programs exist to develop PAFC for stationary power, PEMFC for space and undersea applications, and sources of hydrogen fuel for largescale use. The results of these programs will be incorporated into the transportation program to attain the maximum benefit.
Linkages to these related programs are shown in Exhibit 7.

Fuel cell-powered vehicles could use electric controllers and drivetrains similar to those used in other types of electric vehicles (EVs). Also, some fuel cell vehicle designs use modest amounts of battery storage as a means to handle transient/peak loads. Key drivetrain subsystems are being developed within government/industry-sponsored EV programs and are available for direct incorporation into the fuel cell program. In addition, advanced batteries are being developed for EVs; however, significant development is required to achieve the high power and fast recharge requirements for the FCV application.

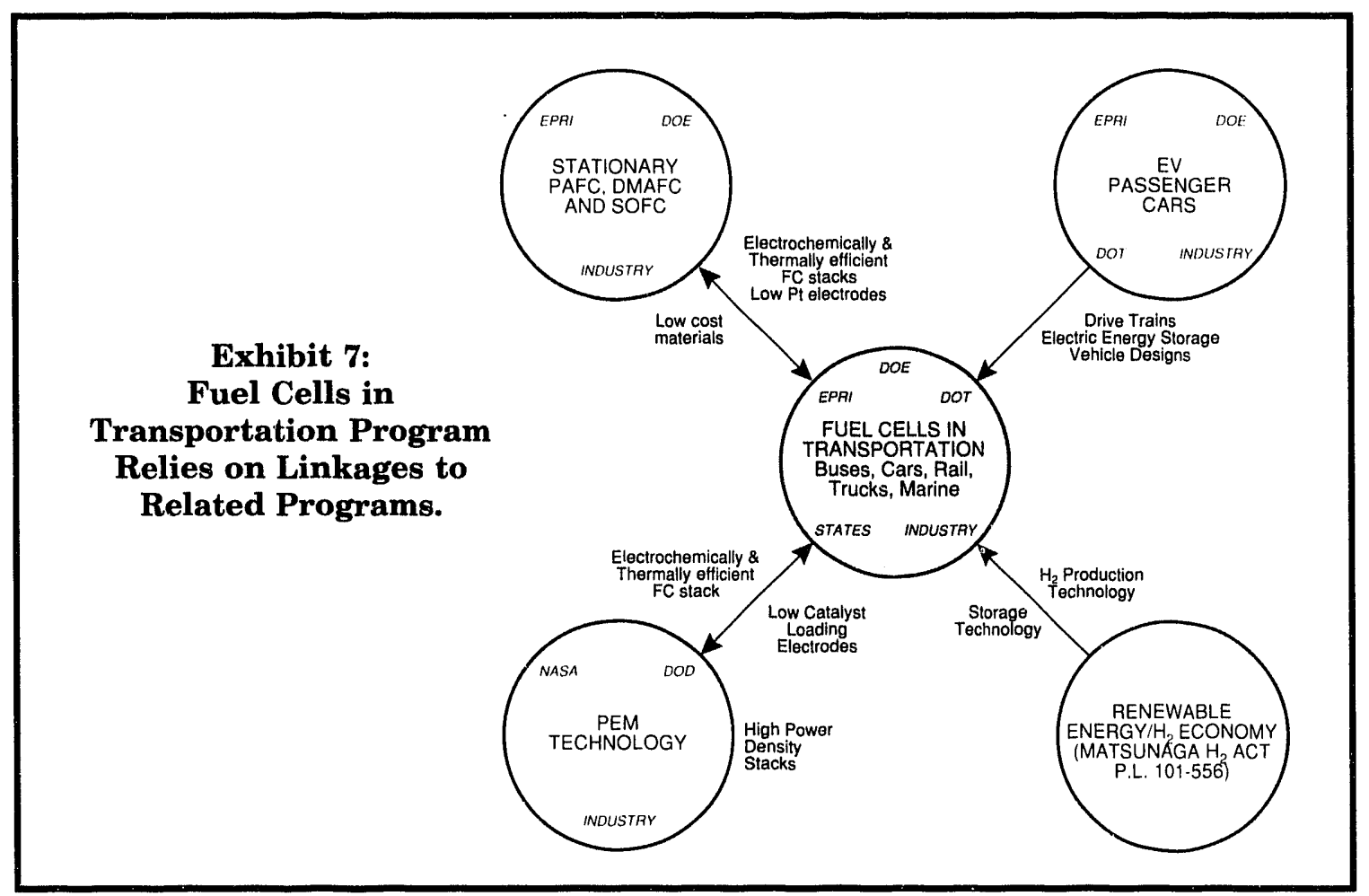




\section{National Program Plan \\ Fuel Cells in Transportation}

\section{THE PROGRAM PROMOTES ENERGY DIVERSITY AND A TRANSITION TO RENEWABLE ENERGY SOURCES.}

Alternative fuels (methanol, ethanol, natural gas, liquefied petroleum gas) or hydrogen can be used in a fuel cell vehicle. These fuels can be derived from a spectrum of energy sources. The potential use of ethanol or methanol produced from renewable energy sources affords an opportunity for a gradual transition to alternative fuels as the supply and distribution infrastructure is built up. The alternative fuels programs are expected to develop the infrastructure needed for distributing ethanol and methanol.

Two basic strategies are being considered for providing the fuel cell stack with a supply of hydrogen at required purity levels:

- On-board fuel processing whereby methanol (or another alternative fuel) stored on the vehicle undergoes reformation and subsequent processing to produce the required hydrogen.
- On-board storage of hydrogen provided by stationary fuel processing facilities.

On-board reformation adds significant complexity to the system; however, it has the advantage of using an alternative fuel for which the distribution infrastructure is already being developed.

On board hydrogen storage is a major thrust of DOE's Hydrogen Program Plan, and would enable the wide-scale use of hydrogen in the transportation sector. The FCV development activities are being coordinated with activities to expand hydrogen production capability under the Matsunaga Hydrogen Act (Public Law 101-556). Because the existing hydrogen market is very small today, production and distribution infrastructures must be developed. 


\section{Procram Description National Program Plan PROGRAM DESCRIPTION Fue Cells in Transportation}

\section{THE PROGRAM CONSISTS OF FOUR ELEMENTS LEADING TO COMMER- CIALLY VIABLE SYSTEMS FOR LIGHT- AND HEAVY-DUTY VEHICLES.}

The Program Plan includes four mutually supporting elements: development of lightduty propulsion systems; development of heavy-duty propulsion systems; supporting research and development; and supporting analysis. Fundamental, exploratory research in basic fuel cell technology is expected to lead to improved fuel cell and system performance for all FCV applications. Research advances made by DOE and other programs will, therefore, be quickly incorporated into system development activities. Exhibit 8 summarizes the program elements.

\section{Exhibit 8: The Program Plan Elements Provide Multiple Opportunities for Success.}

\begin{tabular}{|c|c|c|}
\hline $\begin{array}{l}\text { Light-Duty } \\
\text { Propulsion Systems }\end{array}$ & $\begin{array}{l}\text { Develop PEMFC propulsion systems } \\
\text { for use in light-duty vehicles using } \\
\text { hydrogen and methanol fuels. }\end{array}$ & Proof-of-concept vehicles by 2000 . \\
\hline $\begin{array}{l}\text { Heavy-Duty } \\
\text { Propulsion Systems }\end{array}$ & $\begin{array}{l}\text { Adopt PAFC technology to buses. } \\
\text { Assess feasibility of fuel cell } \\
\text { applications to rail locomotives. } \\
\text { Develop fuel cell-powered rail } \\
\text { locomotives. }\end{array}$ & $\begin{array}{l}\text { Proof-of-concept testing by } 1995 . \\
\text { Feasibility established in } 1996 . \\
\text { Proof-of-concept locomotive } \\
\text { testing in } 1.999 .\end{array}$ \\
\hline $\begin{array}{l}\text { Research \& } \\
\text { Development }\end{array}$ & $\begin{array}{l}\text { Develop improved on-board reformer, } \\
\text { hydrogen storage technologies, and } \\
\text { power management devices. } \\
\text { Conduct laboratory-scale work to } \\
\text { advance fuel cell technology by } \\
\text { improving fuel cell performance and } \\
\text { reliability, and lowering costs. } \\
\text { Investigate advanced concepts and } \\
\text { new technologies, e.g., DMAFC. }\end{array}$ & $\begin{array}{l}\text { Full-scale systems testing in } \\
1997 . \\
\text { Significant improvernents in } \\
\text { PAFC, PEMFC, anc' SOFC by } \\
1998 . \\
\text { Fuel cell stack demonstration by } \\
2003 .\end{array}$ \\
\hline Supporting Analyses & $\begin{array}{l}\text { Assess fuel cell technology benefits } \\
\text { and costs for light- and heavy-duty } \\
\text { applications. Determine energy, } \\
\text { economic, and environmental benefits. } \\
\text { Assess environment, safety, and } \\
\text { health aspects of fuel cells in trans- } \\
\text { portation. } \\
\text { Analyze FCVs versus alternatives, } \\
\text { including infrastructure requirements } \\
\text { Assess manufacturing raw materials } \\
\text { and capital requirements. }\end{array}$ & $\begin{array}{l}\text { Input to feasibility analyses by } \\
1995 . \text { Updated program priorities } \\
\text { by } 1994 . \\
\text { Environmental assessment in } \\
1994 . \\
\text { Market potential of FCVs. } \\
\text { Commercialization strategy. }\end{array}$ \\
\hline
\end{tabular}




\section{National Program Plan Fuel Cells in Transportation}

\section{DEVELOPMEN'T OF LIGHT-DUTY PROPULSION SYSTEMS}

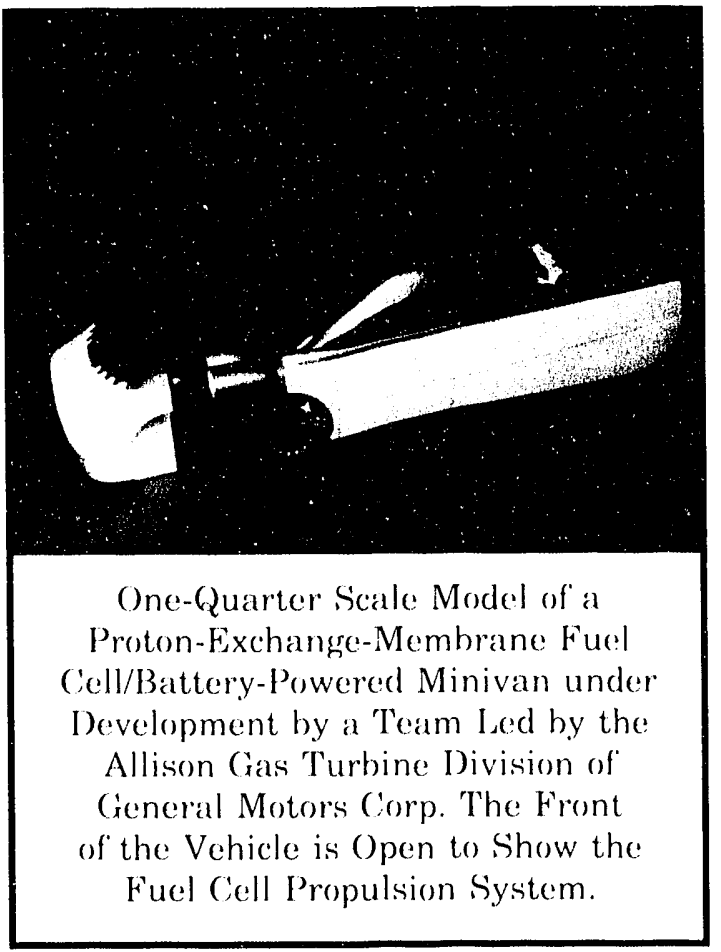

This program is based on the use of PEMFC technology because of its high power density and ability to undergo frequent load cycling. The latter is a requirement of light-duty vehicles (passenger cars, vans, and light trucks), which typically operate only for short periods of time during a day. The ongoing program is based on use of on-board reforming of methanol. Parallel development of a light-duty passenger/utility vehicle powered by a PEMF( system with on-board hydrogen storage is scheduled to begin in 1993. Both projects are expected to advance to the proof-of-concept vehicle stage before a decision is made to proceed to the prototype development stage. Advances in PEMFE: technology and in fuel reforming and hydrogen storage will be directly incorporated into the propulsion system development activities. Decision points at significant milestones in the program allow for periodic redirection of program activities to take full advantage of developments in other program areas.

\section{DEVELOPMENT OF HEAVY-DUTY PROPULSION SYSTEMS}

Fuel cell-powered propulsion systems are being developed for application in heavy-duty vehicles such as buses, railroad locomotives, and trucks. The ongoing Urban Transit Bus Program is based on the use of PAFC, technology, thereby enhancing the prospects for early commercialization due to its well-estahlished technology base. The bus application is typical of heavy-duty vehicles in general and will provide significant public visibility and

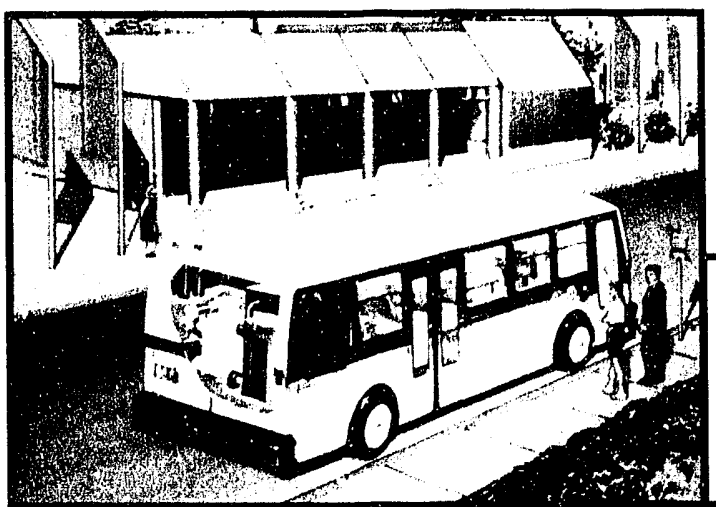
valuable guidance for development efforts on other applications, such as trucks and commuter trains. The early market targeted for this bus is urban areas with acute air-quality problems.

Artist's Rendition of Phosphoric Acid Fuel Cell/Battery-Powered Bus under Development by a Team Led by H-Power Corp. The Cut-a-way at the Rear of the Bus Shows the Fuel Cell Power System. 


\section{National Program Plan Fuel Cells in Transportation}

The DOE and South Coast Air Quality Management District (SCAQMD) will pursue a joint program to develop fuel cell-powered railroad locomotives. The SCAQMD is scheduled to initiate a feasibility study for the use of fuel cells in locomotives in FY 1993. The choice among PAFC, PEMFC, and SOFC technologies will be made during a feasibility evaluation, which will include a determination of the preferred fuel for these applications. As in the light-duty vehicle development, advances in basic fuel cell technology will be transferred to propulsion system activities on an ongoing basis, and decisions to proceed or redirect activities will be made at significant program milestones.

\section{RESEARCH \& DEVELOPMENT}

This program element will focus on the development of key subsystems and fuel cell technologies that will enhance the performance and lower the cost of fuel cell systems. Current component development activities address two areas common to all FCV applica ons:

- Reformer technologies specifically designed for use in transportation applications, incorporating such attributes as load following, low weight and size, and adaptability to multiple fuel use. This program draws heavily on experience with reformers by the chemical process industries and stationary fuel cell developers, so that resources can be focused on transportation-specific issues.

- On-board hydrogen storage systerns appropriate for use on a broad range of vehicles. As such, special attention is being given to transportation-specific issues such as safety, weight and size, and supporting infrastructure requirements (e.g., compressors).
Development of power management devices and concepts is scheduled to begin in FY 19.93. These include high power batteries and ultra capacitors which can store energy recovered from regenerative braking, improve dynamic response, and handle load surges.

Fuel cell research will provide support for the development of fuel iell components with the promise of reduced costs and/or improved performance compared to current fuel cell technology. These activities could include the development of improved materials for PAFC, novel membrane technology for PEMFCs, advanced materials for hydrogen storage, new catalysts, etc.

Fuel cell research will also provide support for advanced technology concepts which show long-term promise of major improvements in performance and cost. Again, primary attention will be given to technology concepts with attractive characteristics for transportation applications. The technologies of current interest for exploratory research are:

- SOFC technology, which shows promise of very high power density, low cost, and ability to directly use a variety of different fuels.

- DMAFC technology, which can utilize methanol directly, thus eliminating the need for a fuel reformer.

Research topics pertinent to the development of fuel cell power systems have been and will continue to be defined by means of a series of workshops at which leading fuel cell researchers discuss research needs and recommend approaches to address these needs. Successful research developments will be quickly incorporated into system-level activities (program elements 1 and 2). A 


\section{National Program Plan Fuel Cells in Transportation}

separate activity on fuel cell technology R\&D minimizes duplication of effort in the system-level programs, yet ensures that adequate attention is given to long-range, high-payoff technologies.

\section{SUPPORTING ANALYSES}

To help ensure that the program proceeds on a sound technical basis, the ongoing supporting analyses address:

- Benefits and cost effectiveness for each fuel cell transportation application. These analyses will be used to establish program priorities.

- Environment, safety, and health aspects in the manufacturing, marketing, operating, maintaining, and disposing of FCVs.

- Technology needs concerning both local and national codes and standards for vehicles and refueling equipment.
- Market potential for applications being considered for system-level development (program elements 1 and 2 above). Included will be an assessment of the performance and cost goals that the fuel cell vehicle must meet in order to compete in the future lightduty and heavy-duty vehicle markets.

The supporting analyses will also inci.1de:

- Evaluation of new technologies, materials, etc, which might significantly alter program direction.

- Analysis of technology options for supporting elements such as refueling infrastructure and common components with electric vehicles.

- Preparation of informational material for use by the public, regulatory bodies, environmental groups, and others with an interest in advanced transportation technology.

The output of such analyses will be important inputs to the ongoing program planning.

\section{THE PROGRAM SCHEDI LE ESTABLISHES THE TECHNOLOGY BASE FOR EARLY APPLICATION'S BY 1995 SO THAT THE COMMERCIALIZATION PROCESS COULD BE UNDERWAY BY THE YEAR 2000.}

The schedule (Exhibit 9) reflects a balance among the four program elements and the need to aggressively develop a technology base that will enhance U.S. competitiveness in the international arena. Key objectives of the schedule are to establish:
- The technical potential for fuel cell automobiles by mid-decade, with fleet demonstrations underway shortly after the year 2000 .

- The technology base for heavy-duty vehicles (buses) by mid-decade, with the commercialization process underway by late in the decade. 
Exhibit 9:

The Research, Development, and Demonstration Schedule for Fuel C

Fuel Cell Power Systems Research, Devi

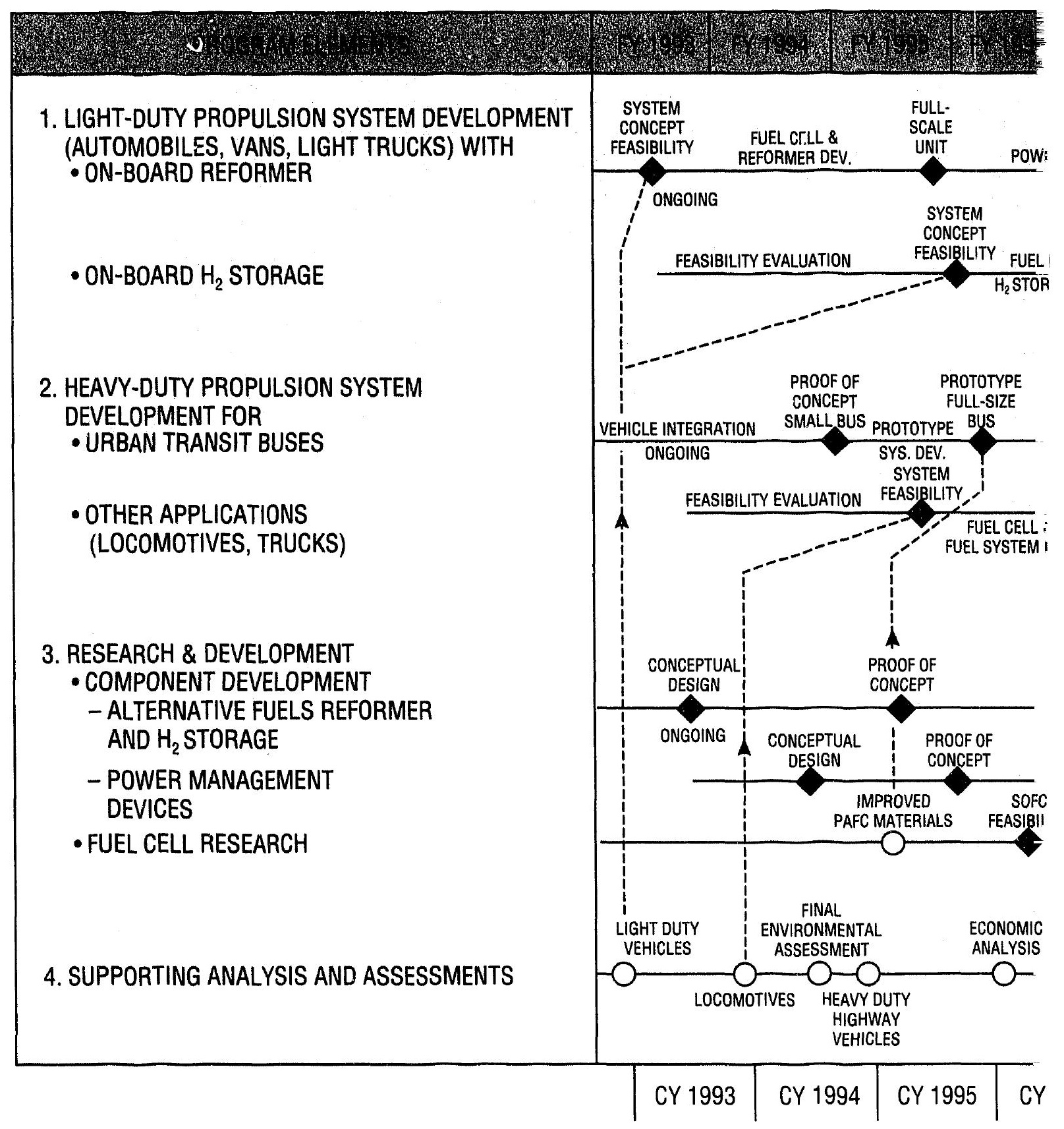




\section{IMPLEMENTATION PLAN $\begin{aligned} & \text { National Program Plan } \\ & \text { Fuel Cells in Transportction }\end{aligned}$}

\section{PRINCIPAL STAKEHOLDERS HAVE DIVERSE INTEREST $:$ WITH A COMMON GOAL.}

While the Program Plan incorporates the necessary elements to develop and deploy fuel cells for transpurtation, these activities must be coordinated with the principal stakeholders. Exhibit 10 identifies the participants or stakeholders and their major interests.

\section{Exhibit 10: Principal Stakeholders Have Diverse Concerns and Potential Contributions.}

\begin{tabular}{|c|c|}
\hline \multicolumn{2}{|c|}{ S. } \\
\hline Automotive Industry & $\begin{array}{l}\text { Investment in production and commercialization of } \\
\text { performance/cost-competitive vehicles. } \\
\text { Compliance with ULEV and ZEV mandates. }\end{array}$ \\
\hline Fuel Cell Manufacturers & Fuel cell development and commerrialization. \\
\hline Fuels Industry & $\begin{array}{l}\text { Infrastructure development and participation in the } \\
\text { processing and distribution of alternative transporta- } \\
\text { tion fuels. }\end{array}$ \\
\hline $\begin{array}{l}\text { Government Agencies } \\
\text { DCE } \\
\text { DOD/DARPA } \\
\text { NASA } \\
\text { NSF } \\
\text { DOT }\end{array}$ & $\begin{array}{l}\text { Development of clean, efficient, quiet transportation } \\
\text { systems puwered by fuel cells based on renewable } \\
\text { energy sources. }\end{array}$ \\
\hline $\begin{array}{l}\text { Regulators including } \\
\text { SCAQMD, CARB, } \\
\text { NESCAUM and EPA* }\end{array}$ & $\begin{array}{l}\text { Development of regulations to mitigate pollution } \\
\text { within acceptable costs. }\end{array}$ \\
\hline Transportation Users & $\begin{array}{l}\text { Environmentally friendly vehicles with performance } \\
\text { and costs better than state-of-the-art. }\end{array}$ \\
\hline
\end{tabular}

South Coast Air Quality Management District (SCAQMD)

California Air Resources Board (CARB)

North East States for Coordinated Air Use Managemeni (NESCAUM)

Environmental Protection Agency (EPA) 
National Program Plan

Fuel Cells in Transportation

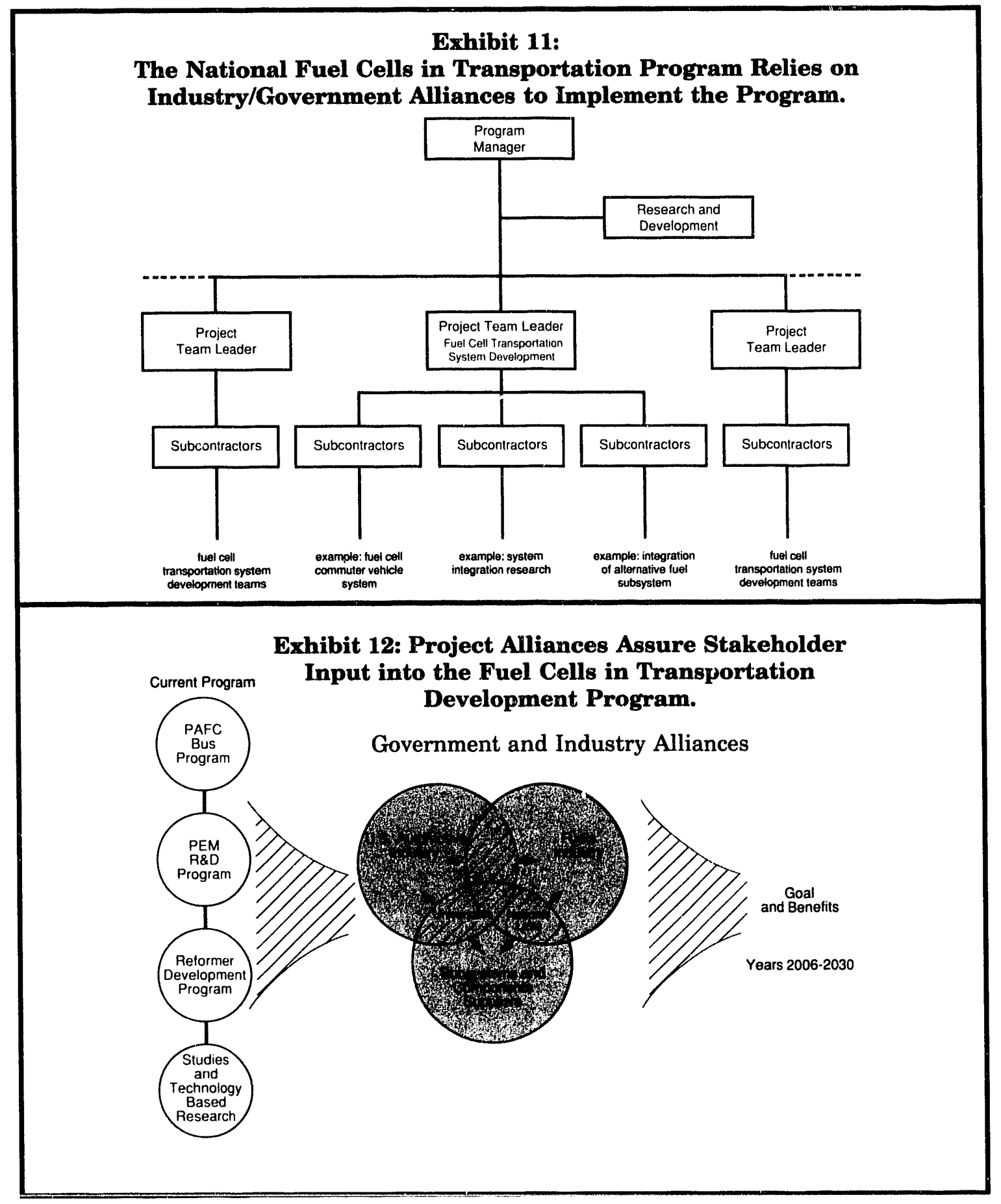




\section{THE FORMATIC N OF ALLIANCES FOR FUEL CELLS IN TRANSPORTATION IS PLANNED TO ENSURE THAT THE PROGRAM REFLECTS THE NEEDS OF THE MAJOR STAKEHOLDERS.}

The current system-level projects are being implemented on a cost-shared basis by teams ("Project Alliances"), including automobile and bus manufacturers, fuel cell technology developers, national laboratories, and component suppliers. The program will continue to implement the system-level projects via such Project Alliances and will seek to expand participation to include a wider range of interested parties, including major fuel suppliers responsible for infrastructure (e.g., the gas industry) and end users of equipment (e.g., transit authorities).

The program manager will integrate activities in all four program areas to ensure that the goals of the development program are met. Exhibit 11 shows the managerial structure of the Fuel Cells in Transportation Program, and Exhibit 12 depicts the integration process necessary to achieve program goals.

An ad hoc technical panel will, as requested by the program manager, provide input based on the expertise of the various stakeholders shown in Exhibit 10 and other interested organizations. Specifically, the ad hoc panel will:
- Review and comment on the program planning process,

- Review and assist with analytical support activities leading to development of the program strategy,

- Exchange information with industry,government, regulators, and other interested parties, and

- Interact with fuel cell associations and advocacy groups.

Program resources will be focused on activities which reflect the needs of industry, government (national/local), environmental groups, and others with an interest in the successful development of fuel cell transportation systems. The formation of Project Alliances will encourage commercial entities to engage in cost-shared $R \& D$ with the confidence that they are investing resources in programs that have broad stakeholder support and consensus. Cost sharing also assures that industrial partners maintain a strong presence in the technology development and participate in determining program direction. The importance of industry/DOE cost sharing thus cannot be overemphasized. 
National Program Plan Fuel Cells in Transportation 


\section{TECHNOLOGY TRANSFER $\begin{aligned} & \text { National Program Plan } \\ & \text { Fuel Cells in Transportation }\end{aligned}$}

\section{THE PROGRAM IS STRUCTURED TO ENSURE RAPID \\ AND COMPLETE TRANSFER OF SCIENTIFIC AND TECHNOLOGICAL RESEARCH RESULTS TO INDUSTRY.}

Technology transfer, or the process by which technological achievement or other relevant information is transferred from a developing or sponsoring organization, is an important element of the Program Plan. Successful technology transfer will help to develop constituencies, avoid duplication of effort, identify opportunities for joint efforts, and reduce risks and costs associated with technology development. Although it is key to the commercialization process, technology transfer is often as difficult or delicate as it is crucial. The primary technology transfer mechanism will be through cost-shared pro- curements under Project Alliances, as described above. Special importance is placed on the use of industry/laboratory teams to achieve the "seamless" transfer of technology. Information exchange will also be an important part of technology transfer and will help to build consensus and constituency for the program by offering opportunities for increased interactions and communication among stakeholders. Cooperative efforts with the DOE Office of Technical and Financial Assistance to facilitate state and local government participation are planned. 
National Program Plan

Fuel Cells in Transportation 


\section{$\begin{array}{ll}\text { SUMMARY } & \begin{array}{l}\text { National Program Plan } \\ \text { Fuel Cells in Transportation }\end{array}\end{array}$}

\section{THIS NATIONAL PROGRAM PLAN FOR FUEL CELLS IN TRANSPORTATION CAN LEAD TO SIGNIFICANTLY REDUCED PETROLEUM DEPENDENCY, IM- PROVED AIR QUALITY, AND ENHANCED INDUSTRIAL COMPETITIVENESS!}

Fuel cells are being developed for application in the transportation sector because they will convert hydrogen to electric power at high efficiencies with virtually no detrimental environmental impact. To realize these energy, environmental, and economic benefits, developers of FCVs need to (1) reduce the size and weight of current designs, (2) develop fuel cell propulsion systems with rapid start-up and greater load-following capability, (3) reduce system cost and/or improve performance, and (4) utilize alternative fuels to a large extent.
This Plan addresses the FCV-related requirements of the Energy Act, describing a development program for light- and heavyduty propulsion systems, a basic R\&D program on fuel cell technology that is separate from, but feeds into, the system development activities, and supporting analyses. Implementation of the Program Plan by means of industry/government alliances will accelerate the commercialization of FCVs. In the long term, the successful deployment of large numbers of FCVs promises to eliminate the transportation sector as a major contributor to the nation's environmental problems. 


\section{National Program Plan Fuel Cells in Transportation}

\section{ACKNOWLEDGMENTS}

The development and production of this Plan was a considerable undertaking, which involved many organizations and individuals whose valuable assistance is herein acknowledged.

DOE is especially grateful to the Ad Hoc Technical Panel and resource personnel for their many valuable comments and contributions to the development of this Plan. The panel and resource personnel met twice to review early draft revisions of the plan and to offer recommendations on plan content and preparation. The panel and resource members are the following:

\section{AD HOC TECHNICAL PANEL FUEL CELLS IN TRANSPORTATION}

Dr. Harlan Anderson,

University of Missouri-Rolla;

Mr. Edward Gillis,

Electric Power Research Institute;

Dr. Patrick Grimes, Exxon;

Dr. Jeffery Gunsher, Dow Chemical USA;

Dr. Richard Lawrance,

U.S. Fuel Cell Manufacturing Corp.;

Dr. Alan Lloyd,

South Coast Air Quality

Management District;

Dr. William Lueckel, International Fuel Cells;

Dr. Paul MacCready, Aerovironment;

Mr. David Mikoryak,

Transportation Manufacturing Corp.;

Mr. Jeffery Serfass/Ms. Debbi L. Smith,

National Hydrogen Association;

Dr. Roberta Nichols/Dr. Mordecai Shelef,

Ford Motor Company;

Mr. George Shishkovsky/

Mr. William Martin,

Chrysler Corporation;

Mr. Gerald Skellenger,

General Motors Research and

Environmental Staff;
Dr. Gene Smith, University of Michigan;

Mr. Albert Sobey,

Albert J. Sobey \& Associates;

Dr. S. Swathirajan,

General Motors Research Laboratories;

Ms. Karen Trimble,

Gas Research Institute.

\section{RESOURCE PERSONNEL \\ FUEL CELLS IN TRANSPORTATION}

Dr. Howard Creveling,

Allison Gas Turbine Division,

General Motors Corp.;

Dr. Shimshon Gottesfeld,

Los Alamos National Laboratory;

Mr. Graham Hagey,

EA Engineering, Science \& Technology;

Dr. James Huff,

Los Alamos National Laboratory;

Dr. Arthur Kaufman,

H-Power Corporation;

Dr. Kim Kinoshita,

Lawrence Berkeley Laboratory;

Dr. Michael Krumpelt,

Argonne National Laboratory;

Mr. Dennis Merens, Dow Chemical;

Dr. James Ohi,

National Renewable Energy Laboratory;

Mr. Paul Prokopius,

National Aeronautics and

Space Administration;

Dr. Vernon Roan, University of Florida;

Mr. Sam Romano, Georgetown University;

Dr. Alan Sylwester,

Sandia National Laboratories;

Ms. Mary Rose Szoka,

National Renewable Energy Laboratory;

Dr. W. Peter Teagen, Arthur D. Little.

¿ U.S. GOVERNMENT PRINTING OFFICE: 1993-747-898 

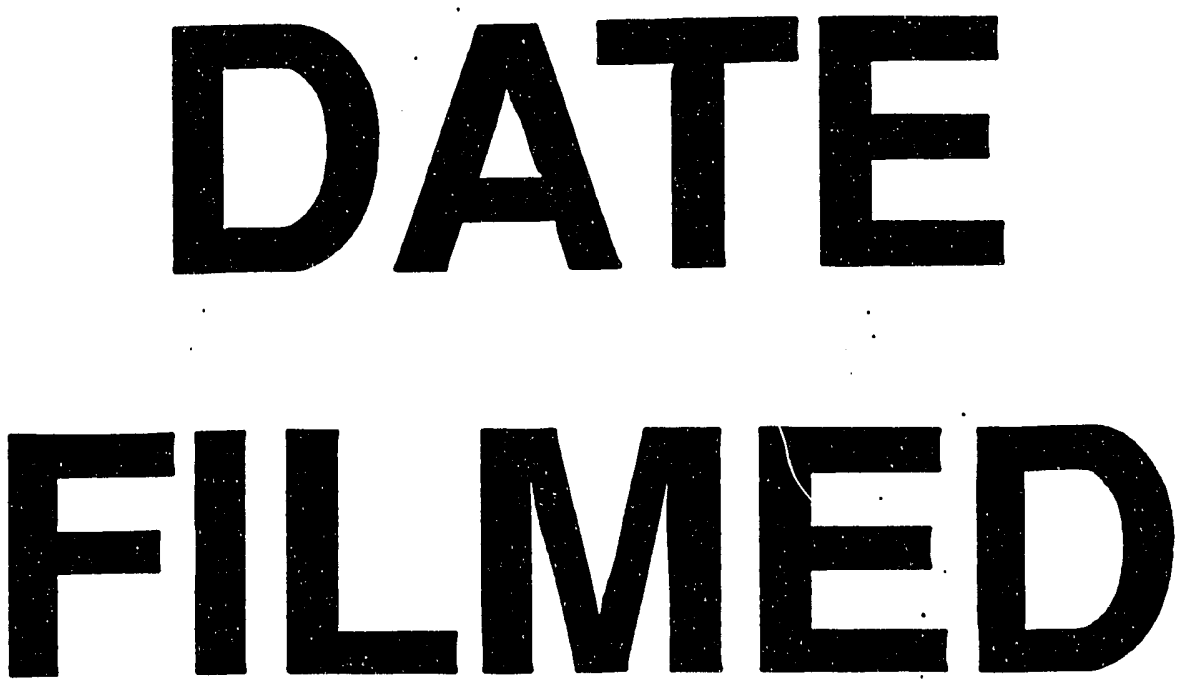

10
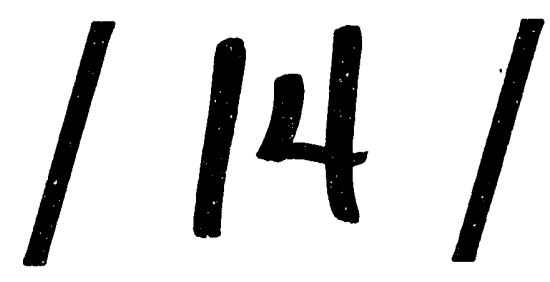

93
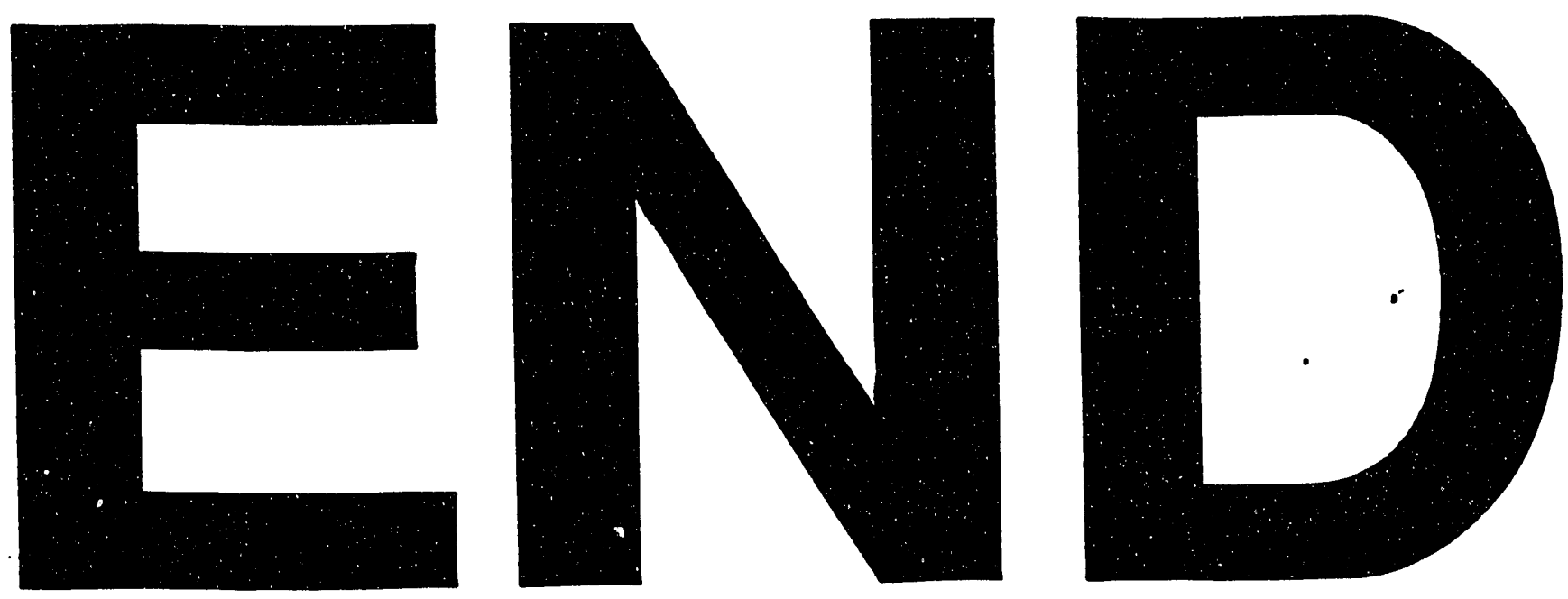
